CORRECTION

\title{
Correction: SLC25A24 gene methylation and gray matter volume in females with and without conduct disorder: an exploratory epigenetic neuroimaging study
}

Elizabeth Farrow (D), Andreas G. Chiocchetti, Jack C. Rogers, Ruth Pauli, Nora M. Raschle, Karen Gonzalez-Madruga, Areti Smaragdi, Anne Martinelli (D), Gregor Kohls, Christina Stadler (D), Kerstin Konrad (D), Graeme Fairchild, Christine M. Freitag (D), Magdalena Chechlacz and Stephane A. De Brito (D)

(c) The Author(s) 2021

Translational Psychiatry (2021)11:553; https://doi.org/10.1038/s41398-021-01643-w

Correction to: Translational Psychiatry https://doi.org/10.1038/ s41398-021-01609-y, published online 24 September 2021

Since the publication of the article the authors have noticed mistakes in the text, figures, tables and supplementary materials. The authors apologize for these errors, which have now been corrected in the original article. Please note that these changes do not affect the results of the paper or their interpretation.

\begin{abstract}
(c) (i) Open Access This article is licensed under a Creative Commons Attribution 4.0 International License, which permits use, sharing adaptation, distribution and reproduction in any medium or format, as long as you give appropriate credit to the original author(s) and the source, provide a link to the Creative Commons license, and indicate if changes were made. The images or other third party material in this article are included in the article's Creative Commons license, unless indicated otherwise in a credit line to the material. If material is not included in the article's Creative Commons license and your intended use is not permitted by statutory regulation or exceeds the permitted use, you will need to obtain permission directly from the copyright holder. To view a copy of this license, visit http://creativecommons. org/licenses/by/4.0/.
\end{abstract}

(๑) The Author(s) 2021 